\title{
62-From the Play to the Story: Writers and Readers of A Jury of Her Peers
}

\section{Yasemin Güniz SERTEL ${ }^{1}$}

APA: Sertel, Y. G. (2022). From the Play to the Story: Writers and Readers of A Jury of Her Peers. RumeliDE Dil ve Edebiyat Araştırmaları Dergisi, (26), 1004-1013. DOI: $10.29000 /$ rumelide.1074146.

\begin{abstract}
The purpose of this article is to study Susan Glaspell's story A Jury of Her Peers from the perspective of the reader-response criticism which emphasizes the significance of the readers as active participants in reading and evaluating a text. In this criticism, the active reader is endowed with the responsibility of generating a message or a meaning from the text. A Jury of Her Peers offers a metatext of a murder mystery waiting to be solved by its active readers. The absent voice of the story Minnie Wright is suspected of being the murderer of his husband while she leaves behind a series of clues which have to be read as hidden texts with their hidden messages, leading their readers to the motives behind the murder case. As the text is read both by male and female characters/readers in relation with their gender roles, a feminist perspective adds a further connotation to the readerresponse criticism of the text. Since male characters evaluate the situation with their prejudices shaped by the priority of a patriarchal perspective, they cannot read the hidden messages. Yet, they even cannot find a text to be read. However, female characters identifying themselves with Minnie are capable of finding all the clues and reading all the messages hidden in the text of Minnie. And they solve the mystery of the crime. Hence, they not only celebrate their common membership in sisterhood but they also experience a transformation towards their autonomous selves.
\end{abstract}

Keywords: dialectical text, rhetorical text, feminist criticism, reader-response criticism

\section{Oyundan Öyküye: A Jury of Her Peers'ın Yazar ve Okurları}

Öz

Bu makalenin amacı, Susan Glaspell'in A Jury of Her Peers adlı öyküsünü okur-odaklı kuram ışı̆̆ında değerlendirmektir. Okur-odaklı kuram, bir metnin okunmasında ve değerlendirilmesinde okurların aktif katılımcılar olarak önemini vurgular. Bu bakış açısına göre, okuyucu metinden anlam üretmek veya metinleri/mesajları çözümlemekle sorumludur. Bir cinayet hikayesini anlatan A Jury of Her Peers öyküsünün gizemi aktif okurları tarafından çözümlenmeyi beklemektedir. Öykü boyunca hakkında çok tartışmalar yapılan ancak öznel sesini hiç duymadığımız Minnie Wright, kocasının katili olarak gözaltında tutulmaktadır. Ancak geride bıraktığı eşyaları içerdiği gizli mesajlar ve ve ipuçlarıyla, onu cinayete yönlendiren metinler olarak değerlendirilir/okunur. Bu meta-metinler kadın ve erkek karakterler/okurlar tarafından toplumsal cinsiyet rollerine göre okunup değerlendirildiği için metnin okur-odaklı çözümlemesi feminist bir bakış açısı ile yeni bir anlam kazanır. Öykünün erkek karakterleri durumu ataerkil bakış açıları ve önyargılarıyla koşullu bir şekilde değerlendirdikleri için ne bir mesaj ne de okunacak bir metin bulabilirler. Ancak Minnie ile empati kurabilen kadın karakterler tüm ipuçlarını görür, Minnie’nin metninde gizlenmiş mesajları

Dr. Öğr. Üyesi, İstanbul Üniversitesi, Edebiyat Fakültesi, Batı Dilleri Bölümü, Amerikan Kültürü ve Edebiyatı ABD (İstanbul, Türkiye), gsertel@istanbul.edu.tr, ORCID ID: oooo-0002-1249-7427 [Araştırma makalesi, Makale kayıt tarihi: 17.12.2021-kabul tarihi: 20.02.2022; DOI: 10.29000/rumelide.1074146]

Adres $\mid$ Address

RumeliDE Dil ve Edebiyat Araştırmaları Dergisi Osmanağa Mahallesi, Mürver Çiçeği Sokak, No:14/8 Kadıköy - İSTANBUL / TÜRKIYE 34714 e-posta: editor@rumelide.com tel: +90 5057958124, +90 2167730616

RumeliDE Journal of Language and Literature Studies

Osmanağa Mahallesi, Mürver Çiçeği Sokak, No:14/8

Kadıköy - ISTANBUL / TURKEY 34714

e-mail: editor@rumelide.com,

phone: +90 5057958124 , +90 2167730616 
okur ve cinayetin sırrını çözerler. Böylece hem ortak kadın öznelliklerini kutlamış olur hem de özerk kimliklerini bulmakla sonuçlanan bir değişim süreci geçirmiş olurlar.

Anahtar kelimeler: diyalektik metin, retorik metin, feminist eleştiri, okur-odaklı eleştiri

\section{Introduction}

A Jury of Her Peers is a short story version of Susan Glaspell's play Trifles which was performed by the ProvinceTown Players in 1916. Inspired by a real incident, A Jury of Her Peers explains a murder story in which Minnie Wright, a woman living in an isolated farm house in the rural regions of Dickson County strangulates his husband while he is asleep. During the story, the County Attorney and the Sheriff make their investigations in the farmhouse while they are accompanied with Lewis Hale, a neighbor farmer who is the first person to realize the murder. Wives of the Sheriff and Lewis Hale (Mrs Peters and Mrs Hale) are also brought to the murder house in order to take some belongings of Minnie that she might need in the jail. During their investigation, men as the figures of authority are not able to find any clues to motivate Minnie for the murder as they disregard and belittle the simple tools of women especially in the kitchen. However, those simple tools mentioned as 'trifles' by men are the real clues of the murder and women realize their significance since they use similar tools in their daily lives and thus they solve the mystery of the murder. However, comprehending Minnie's situation and identifying themselves with her, women decide to keep silent and they do not share their knowledge with their husbands with the intention of protecting Minnie.

The capability of women in understanding the motives behind the murder and their ability to realize the significance of Minnie's belongings left behind such as the kitchen tools, half-finished housework, an empty bird cage and a half-made quilt transform the murder case into a big puzzle to be solved as well as becoming an important text awaiting to be read. As a matter of fact, throughout the story, all these clues become "a silent witness awaiting the translation of its visual signs into verbal language" (Sözalan, 2006: 28). However, the different reactions of men and women towards these clues in question force the reader to make a reading of the text from the perspective of the reader-response criticism. In reader response criticism, it is the responsibility of the reader to become an active interpreter of the text he/she reads. Rabinowitz interprets this role of the reader "as being governed not by what is in the text but, rather, by what readers bring to the text from outside" (qtd. in Schwarz, 1994:132). In other words, the reader is expected to give voice to the mute messages in the text. However, in this perspective, there is also a "connection between acts of reading or interpretation that are performed by characters within the text and the problems that we, as readers, face in interpreting the interpreters" (qtd. in Schwarz, 1994:132). Besides this approach, since the reading of Minnie's texts throughout A Jury of Her Peers also gives the message that "male indifference and cruelty towards women entail violence and death", the text requires a feminist reading as well (Sözalan, 2006: 24).

\section{Minnie Wright as an Author}

As A Jury of Her Peers is about reading and re-reading of a murder story, different perspectives of men and women towards the clues left behind remind us of the "multiplicity of organization" of a "reading experience" which emphasizes "curiously contradictory" perspectives of different readers within readerresponse criticism (Schwarz, 1994: 127). These contradictory approaches to the same text have their roots in E.D. Hirsch's "doctrine of critical relativity" which asserts that different people have different understandings of the same text. As Hirsch suggests, "everybody sees literature from his own angle of

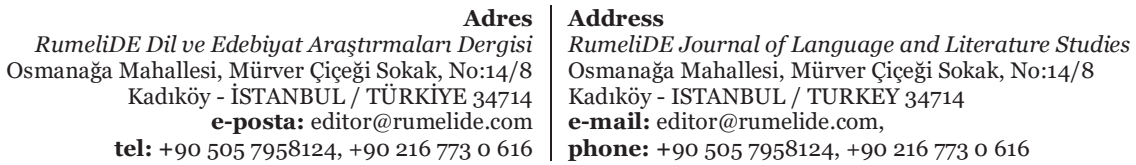


1006 / RumeliDE Journal of Language and Literature Studies 2022.26 (February)

From the Play to the Story: Writers and Readers of A Jury of Her Peers / Y. G. Sertel (pp. 1004-1013)

vision and respond emotionally to [the text] through his own system of values and associations" (Hirsch, 1988:231). Roland Barthes also exemplifies the "doctrine of critical relativity" when he refers to the reading experience as "a multidimensional space in which a variety of readings... blend and clash. The text [becomes] a tissue of quotations drawn from the innumerable centers of culture"(Barthes, 1988:149). Under the light of these discussions, Wolfgang Iser refers to another dimension of the readerresponse theory in his work The Reading Process: A Phenomological Approach. In this work, he interprets the role of the author and the reader in a literary work in relation with "artistic" and "aesthetic"poles: "The literary work has two poles, which we might call the artistic, and the aesthetic: the artistic refers to the text created by the author, and the aesthetic to the realization accomplished by the reader" (Iser, 1988: 189). Therefore, in A Jury of Her Peers what Minnie leaves behind as clues comprises the artistic pole of the story and they make her the author of these clues which are waiting to be read and interpreted by the readers. Throughout A Jury of Her Peers women have no difficulty in understanding Minnie's situation. Since they are living under the same circumstances, they have common experiences with Minnie. On a more general level, as women they share the same destiny so, they can read and understand the text written by Minnie through the clues she left behind. On another level, living in a rural place and leading a farmer's life like Minnie, they can identify themselves with her and understand how lonely she was in that "lonesome-looking place... down in a hollow and the poplar trees around it were lonesome-looking trees" (Glaspell, 1918: 1) which does not even see the road. Besides, they know that Minnie has not been happy in her marriage with John Wright "a hard man... to pass the time of the day with" (Glaspell, 1918: 8) who does not want even a telephone at his home - thus rejecting the possibility of Minnie's communication with other people. So, as Mrs Hale suggests, marriage with a hard man like John Wright adds further problems to the difficulties of living in a place of isolation: "I don't think a place would be any cheerfuler for John Wright's being in it"(Glaspell, 1918: 4). As a matter of fact, living in such an "extreme geographical isolation" in Dickson County reminds the reader of the difficult life conditions of the nineteenth century piooneers and farmers in the western open lands and prairies. Hedge refers to this difficult life style of -especially- women in the prairies as follows:

When a male Pioneer registered his sense of the land's emptiness, it was often to recognize that the emptiness bore more heavily upon women... In Minnesota territory in 1850 os and in the middle northwest in 1870 s the prairie has a solitude way beyond the mere absence of human beings... Women, he observed, especially suffered. They "fled in terror", or "stayed until the prairie broke them." Women themselves reported that it was not unusual to spend five months in a log cabin without seeing another woman... or to spend one and a half years after arriving before being able to take a trip to town. The absence both of human contact and of any ameliorating features in the landscape exacerbated the loneliness felt by women who had often reluctantly uprooted themselves from eastern homes and families in order to follow their husbands westward (Hedges,2002: 53-54).

As Hedge continues to explain, such an extreme isolation accompanied with the diffucult duties of a farm woman - as in the case of Minnie Wright- can lead women into experiencing a psychological disorder:

Here again Glaspell's story reflects a larger truth about the lives of rural women. Their isolation induced madness in many. The rate of insanity in rural areas especially for women, was a much discussed subject in the second half of the nineteenth century. As early as 1868 Sarah Josepha Hale, editör of the influential Godey's Lady's Book, expressed her concern that the farm population supplied the largest proportion for the nation's insane asylums (Hedges,2002: 59).

Hedge's sociological studies given in the above quotations reflect the actual experiences of many women left in isolation in rural places. Although Minnie is not reflected as a complete insane character in the story, her loneliness and her unhappiness in her marriage accompanied with the loss of her only

RumeliDE Dil ve Edebiyat Araştırmaları Dergisi Osmanağa Mahallesi, Mürver Çiçeği Sokak, No:14/8 Kadıköy - İSTANBUL / TÜRKIYE 34714 e-posta: editor@rumelide.com tel: +90 $5057958124,+90216773$ o 616
Address

RumeliDE Journal of Language and Literature Studies

Osmanağa Mahallesi, Mürver Çiçeği Sokak, No:14/8

Kadıköy - ISTANBUL / TURKEY 34714

e-mail: editor@rumelide.com

phone: +90 $5057958124,+902167730616$ 
company, namely her bird gives harm to her psychological health and leaves her in an unstable psychology. Even social psychologists emphasize the significance of isolation as a symptom of depression in the lives of farm women: "Women, often active as agricultural partners in farm operation, may be at higher risk for depressive symptoms as they attempt to juggle a multitude of farm and family responsibilities. Feelings of isolation and loneliness are compounded by the rural location of farms and the nature farm work. Taken together, these environmental and social influences may contribute to the depressive symptoms" (Corruth \&Logan, 2002: 214).

Since these conditions are experienced by many women in rural places and thus become their common experience, Minnie's problems can also be accepted as the reflections of Mrs Hale's and Mrs Peter's experiences. Hence, the text written and hidden in the house, in the kitchen tools or in the quilt is according to women not a mystery to be solved, but a reflection of their subjective positioning. Yet, men who are responsible for solving the crime case as the patriarchal leaders of the society do not even realize the significance of these clues since they are only trifle kitchen tools of women. The Sheriff shows his reaction to these trifles with these words: "Nothing here but kitchen things, he said with a little laugh for the insignificance of kitchen things"(Glaspell, 1918: 3). Mr Hale also supports him by saying: "Women are used to worrying over trifles" (Glaspell, 1918: 4). As a matter of fact, men are looking for real clues "that would point to any motive" (Glaspell, 1918: 3) as the presence of a gun or a forced window. According to Christopher Bigsby,

It is, however, the very trifles of domestic life which the men so casually dismiss that contain the real clues to the despair, the anxiety and the tension which in all probability explain the crime which so baffles them. It is not simply that supposedly trained observers fail to realize the significance of the details which confront them, but that their own male arrogance stands between them and understanding. Their myopia is a product of a more fundamental failure - a failure of human concern and emotional sensitivity. That failure is precisely at the root of the crime which they set out to investigate (Bigsby, 2000: 10).

As a matter of fact, men evaluate the situation with their assumptions and prejudices which have their roots in the problem of gender and sexuality shaped by the priority of a patriarchal perspective. Hence, leaving aside the appreciation of those tools as clues, they even do not see a text to be read among those "trifles". According to Fetterley, "it is not simply that the men cannot read the text that is placed before them. Rather, they literally can not recognize it as a text because they cannot imagine that women have stories" (Fetterley, 1986: 147-148). It is this humiliative and belittling attitude that leads women not to share what they have found as the real clues of the murder with their men. As a matter of fact, men's rejection of finding a text or reading it can also be related to their subjective positionings. Because, the realization or the acceptance of those tools as hints of Minnie's suffering in her unhappy marriage with an indifferent and a hard man would lead men to confront and to accept their own indifference, insensitivity or arrogance towards women. As representatives of this masculine perspective, men know women only with their names of marriage denying a private identity for them and referring to Sheriff's wife as Mrs Peters who is "married to the law"; a condition accepted as the ultimate essence of her existence. So Mrs Peters is expected to read the texts and stories of men, not of women. Therefore, different perspectives of men and women in A Jury of Her Peers have their roots in the different positionings of them in relation with their gender roles. And these different positionings throughout the story can be accepted as the exemplifications of E.D. Hirsch's "doctrine of critical relativity" or Stephen Booth's "multiplicity of organizations" of a reading experience within the reader-response criticism.

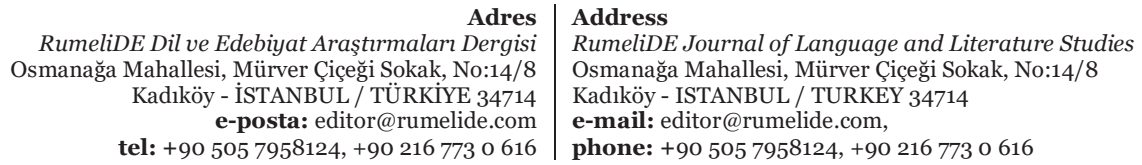
tel: $+905057958124+902167730616$
Address

RumeliDE Journal of Language and Literature Studies

Kadıköy - ISTANBUL / TURKEY 3471

phone: +90 5057958124, +90 2167730616 
1008 / RumeliDE Journal of Language and Literature Studies 2022.26 (February)

From the Play to the Story: Writers and Readers of A Jury of Her Peers / Y. G. Sertel (pp. 1004-1013)

\title{
Readers of Minnie Wright's Texts
}

The different perspectives acquired during the reading process is examined in two categories in Wolfgang Iser's work The Act of Reading: A Theory of Aesthetic Response such as the "implied reader" and the "actual reader" (qtd. in Schwarz, 1994:127). The actual reader is the one who reads what he sees before him without realizing the significance of the texts, their various symbols and possible connotations. Therefore, in A Jury of Her Peers, men become the actual readers who see only a mess in the kitchen and who perceive Minnie as a woman with no "home-making instinct" (Glaspell, 1918: 4). On the other hand, Iser defines implied reader as "the reader whom the text creates for itself and amounts to a network of response inviting structures which predispose us to read in certain ways" (Brooker, Selden, Widdowson, 1997: 56). So the implied reader becomes the active reader who realizes the significance of all the symbols or the different connotations of the text implied by its author. In other words, the implied reader is the active interpreter who is able to read the hidden messages given in the text. Moreover, Iser's theory in The Reading Process: A Phenomological Approach mentioned at the beginning parts of this article brings another dimension to the position of the different readers (implied reader and actual reader). Iser defines the role of the readers in relation with the aesthetic pole of a literary text. The aesthetic pole is "the realization accomplished by the reader" (Iser, 1988: 189). Studying A Jury of Her Peers from Iser's perspective in relation with the aesthetic pole, it is possible to refer to the responses of the implied and actual readers as various realizations experienced by the male and female characters. Within this pole, the text brings a kind of illumination and an effect on the readers. Therefore, the readers' reactions to the texts, namely the clues left by Minnie provide the fundamentals of the aesthetic pole in the story. The aesthetic pole also provides "a virtual dimension" to the reading process by combining the text with the imagination of the reader. Iser explains this virtual dimension as follows:

\begin{abstract}
The fact that completely different readers can be differently affected by the 'reality' of a particular text is ample evidence of the degree to which literary texts transform reading into a creative process that is far above mere perception of what is written. The literary text activates our own faculties, enabling us to recreate the world it presents. The product of this creative activity is what we might call the virtual dimension of the text, which endows it with its reality. This virtual dimension is not the text itself, nor is it the imagination of the reader: it is the coming together of text and imagination. The activity of reading can be characterized as a sort of kaleidoscope of perspectives, preintentions, recollections (Iser, 1988:192).
\end{abstract}

The virtual dimension in A jury of Her Peers is the unity achieved when the clues left by Minnie are interpreted in different ways by the male and female characters and thus, even the character of Minnie is constructed in contradiction with each other in the minds of men and women. Throughout the story, women become the implied readers, that is, the active interpreters of the text written by Minnie by following the clues carefully and by identifying themselves with her. The first text that the women read is the untidy kitchen with the dirty towels, unwashed pans in the sink, half-baked bread and the flour left on the table. In feminist theories, the house, especially the kitchen is defined as the private-service sphere of women. As the name suggests, it is the place where they belong with all its privacy and it is the place where they are expected to serve. In principle, women are expected to do the housework, look at their children and serve their husbands in this private-service sphere. It is also expected from women to keep this place of belonging neat and in order and work/live here functionally. A deviation from this order labels women as abnormal therefore, the disorder in Minnie's kitchen is interpreted by the County Attorney Mr Henderson as follows: "I shouldn't say she had the home-making instinct" (Glaspell, 1918: 4). On the other hand, women are able to realize that something wrong has happened in that house and all that disorder is the outward reflection of Minnie's anger, anxiety and disordered psychology after the

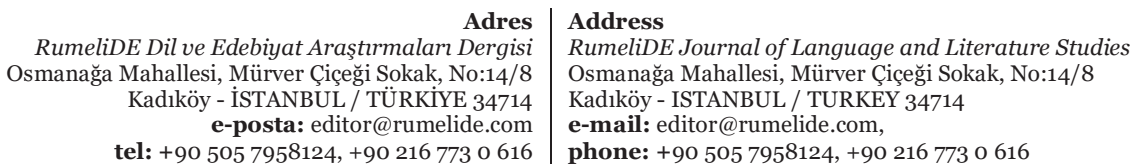


death of her husband. As a matter of fact, these are the motives behind the murder that men are desperately looking for. Women's ability to read the disordered situation of the kitchen has its roots in the common experiences of women which can be defined as the female subjective position. In other words, women's common experiences as wives of farmers living in the same environment under similar conditions and sharing the similar experiences frame their perspectives as female subjects. As female subjects, their common burdens of life allow Mrs Hale and Mrs Peters to empathize with Minnie's psychology. Therefore, when Mrs Hale looks at Minnie's untidy kitchen with all the half-finished work, she remembers her own untidy kitchen when the investigation team comes to bring her that morning:

She thought the flour in her kitchen at home - half-sifted, half not sifted. She had been interrupted, and had left things half done. What had interrupted Minnie? Why had that work been left half-done? She made a move as if to finish it - unfinished things always bothered her (Glaspell, 1918:5).

Identifying herself with Minnie Mrs Hale knows that the kitchen in a mess is not the proof of Minnie's lack of a home-making instinct, but it is a sign of her worries and anxieties which hinder her to accomplish her private-service sphere duties. As a matter of fact, gender roles impose some responsibilities on man and woman which have to be accomplished under any circumstances. In patriarchal societies, female-gender role forces women to accomplish the housework without a mistake disregarding her psychological situation. This expectation has framed the understanding of the male characters when they see the mess in the kitchen. However, this mess -as suggested also by the American Psychological Association- is a proof of an "adjustment disorder" among "gender related acute stress disorders" which is accepted as "more prevalent among females" and which generally reveals itself "after trauma exposure" (APA, 2013: 285). In clinical psycholohy, trauma exposure includes cases like "exposure to actual or threatened death" by "directly experiencing the traumatic events" or "witnessing, in person, the event(s) as it occurs" (APA, 2013:280). Without doubt, what Minnie experiences in the midst of her dirty and untidy kitchen is acute stress disorder which also shows itself in an "extreme level of anxiety" and which results in "incapacity to attend to tasks" and "withdrawal from many situations [as] absenteeism from work" (APA, 2013: 285).

Besides the kitchen, another text women as implied readers are able to read in Minnie's house is the broken bird cage and a strangulated bird with a broken neck wrapped in a piece of silk. The bird and its singing has been a source of life for Minnie in her lonely life. Living in an isolated farm house with an indifferent man who deprives Minnie of any communication by rejecting to have even a telephone wire since "all he asked was peace and quiet" (Glaspell, 1918: 2), John Wright is disturbed even by the voice of the bird. The women examine the dead bird carefully and realize that it is strangulated by John Wright: "No, Wright wouldn't like the bird... a thing that sang. She used to sing. He killed that too" (Glaspell, 1918: 9). Since Minnie experiences an ultimate loneliness when her husband is working on the farm for the whole day, the bird becomes her only company. Being deprived of its singing as well as being a witness to its murder make Minnie experience a psychological instability (adjustment disorder). As a reaction to the murder of the bird, Minnie in her uncontrollable anger kills her husband by strangulation while he is asleep. Hedges also refers to the strangulation of the bird as a motive for Minnie's murderous inclinations and her unstable psychology showing itself as the result of an acute stress disorder:

That the loss of her music, in the shape of a bird, should have triggered murderous behavior in Minnie Wright is therefore neither gratuitous nor melodramatic... In the monotonous expanses of the prairie and the plains, the presence of one small spot of color, a bit of music, might spell the difference between sanity and madness (Hedges, 2002:59-60).

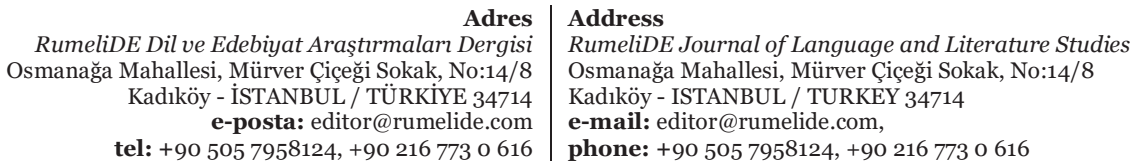


The strangulated bird wrapped in silk reminds Mrs Hale the death of her first baby and the unbearable silence and loneliness she has experienced after that incident: " 'I know what stillness is', she said in a queer, monotonous voice. 'When we homesteaded in Dakota, and my first baby died - after he was two years old- and me with no other then'...”( Glaspell, 1918: 9). One of the characteristics of the implied readers is their ability to generate a meaning which is not openly mentioned in the text by its author. As mentioned in Interaction between Text and Reader, "what is missing from a narrative causes the implied reader to fill in the blanks creatively" (Schwarz, 1994: 128). As a result of her implied reader position, Mrs Hale's female subjectivity also reads the bird as a child, a baby of Minnie that she has never had and, the absence of the bird/baby as the loss of the meaning of her life: "I wonder how it would seem, Mrs Hale at last began, as if feeling her way over strange ground- never to have had any children around"( Glaspell, 1918: 9). Besides replacing the child Minnie has never had, the bird also represents the identity of Minnie as a cheerful choir singer in her girlhood. Mrs Hale remembers those happy days of Minnie as follows: "I wish you'd seen Minnie Foster... when she wore a white dress with blue ribbons, and stood up there in the choir and sang"(Glaspell, 1918: 9). Therefore, in the dead body of the bird, Mrs Hale reads the spiritual death of Minnie as well.

Wolfgang Iser refers to another feature of the implied readers as their potential of acquiring "certain mental images in the process of reading; however, the images will inevitably be colored by the reader's existing stock of experience" (qtd. in Selden, Brooker, Widdowson: 1997: 56). In this process, "the stock of experience" becomes revitalization of the past incidents and memories for the reader because "we [as readers] hold in our minds certain expectations, based on our memory of characters and events" (qtd. in Selden, Brooker, Widdowson: 1997: 56). In A Jury of Her Peers, as a result of the combination of the mental images received from the dead bird with the past incidents, remembrances and memories, Mrs Peters (wife of the Sheriff who is married to the law) also experiences a kind of awakening and then an identification with Minnie. She remembers her suffering when her cat was killed by a boy in her childhood memories:

'When I was a girl', said Mrs Peters, under her breath, 'my kitten - there was a boy took a hatchet, and before my eyes - before I could get there-' She covered her face an instant. 'If They hadn't held me back I would have'... she caught herself, looked upstairs where footsteps were heard, and finished weakly - 'hurt him' (Glaspell, 1918: 9).

Hence, in the dead bird, Mrs Peters reads the rage of Minnie combined with her unbearable pain. Reading this anger initiates a journey into Mrs Peter's childhood as well. And the combination of the "mental images" with her own experiences in the past forces Mrs Peters to keep the reason behind the murder as a secret between herself and Mrs Hale. Thus, she experiences a transformation from "the wife of the law" into an autonomous woman who decides to protect Minnie: "Then her eyes pointed the way to the basket in which was hidden the thing that would make certain the conviction of the other woman - that woman who was not there and yet who had been there with them all through that hour" (Glaspell, 1918: 11).

The most important text that women as implied readers are able to read is the half-finished quilt left in the sewing-basket. Throughout the story, the quilt-making has a significance both in women's culture especially in a rural area and also for the evaluation of the text according to the reader-response criticism. Karen F. Stein summarizes the importance of quilt-making as an essential social activity in women's culture as follows:

Quilts were made primarily for their utility; but they also offered an outlet for creativity that often had no other available channel of expression. For the many women who had no knowledge of reading

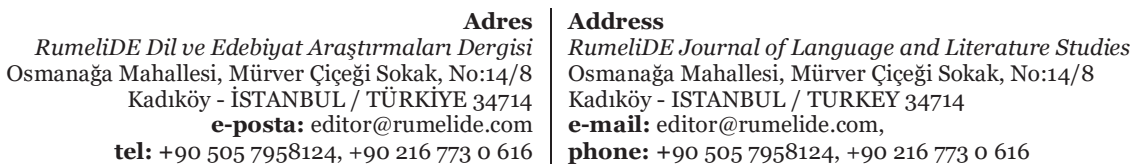


and writing, and who could not have spent their time in such non-productive activities, patchwork became a means of artistic self-expression. In the quilt patterns and the names for them that their makers devised, women told the stories of their lives. The quilting itself... was done in a communal setting... Groups of women would gather around the quiting frame to cooperate in the tedious task of quilting. The quilting bee was one of the main social events for women whose daily lives kept them isolated from each other (Stein qtd. in Chinoy \& Jenkins, 1981: 254-255).

The messages written on the sewings have also become an important aspect of women's culture. Quilting becomes the first lesson that mothers have to teach their daughters and thus, quilting/ sewing contains messages in itself that has to be transmitted from one generation to the next. In the patterns of those quilts and in the names given to those patterns, women's culture -exemplified in various stories- is recorded. Names of the patterns as "Log Cabin, Baby's Blocks, Corn and Beans, Covered Wagon Trail, Underground Railroad and Union Star" reflect not only women's "daily routines" but also their interest in social and political incidents. (Stein qtd. in Chinoy \& Jenkins, 1981: 254-255) Messages written on the sewings and quilts have also become a source for the mythological stories in relation with women's position. Among these stories, Procne's story is the most famous one in Greek mythology which tells the story of the messages weaved on a wedding robe:

In the myth, Terseus is enchanted by the voice of his wife Procne's younger sister Philomela, and falls in love with her. Having been told by his son-in-law that his daughter is dead, Pandion sends Philomela to replace his sister... When Procne finds out about her husband's treachery... in slaves' quarters, she manages to weave a secret message... into the bridal robe intended for Philomela (Sözalan, 2006: 31).

Procne's message weaved on the wedding robe and her desire for revenge directly remind us of Minnie's message written on her own quilt and her desire to take the revenge of her precious bird. Therefore, through the quilt she has made, Minnie gives voice to her feelings, anxieties and frustrations. The quilt becomes the channel through which she explains her pain and suffering to Mrs Hale and Mrs Peters. What attracts the attention of these two women in Minnie's quilt is the disorder in the last half-finished quilt whereas the rest of the patchwork is sewed in a regular way. Comparing the disordered quilt with the rest of the patchwork, they realize that Minnie "didn't know what she was about" and "she was so nervous about" something that has happened (Glaspell, 1918: 7). Therefore, the disordered quilt as a text becomes "an instance of parole, a coded message which contains the silenced woman's narrative that can only be decoded by other women" (Sözalan, 2006: 30). This written message tells Mrs Hale and Mrs Peters that Minnie is suffering because of the death of her bird/her baby which has become the only joy in her life and because of this pain, she is on the verge of madness. And thus, she is not able to control herself and thus she can do everything. As a matter of fact, this is the real clue that men are desperately searching for in the upstairs.

Considering this as a message on the quilt, Mrs Hale and Mrs Peters become sure of the motives behind John Wright's murder. However, their reaction becomes protecting Minnie against the harsh male society with its injustices and laws. With these thoughts on her mind, Mrs Hale "threaded a needle and started to replace bad sewing with good" (Glaspell, 1918: 7). This act is Mrs Hale's rebellion against the dominant male authority and its hegemony since by replacing the disordered patterns in the quilt with the good ones, she erases Minnie's text after she reads it thus, all the clues are wiped out. And this act becomes the pact of the mute communication between the two women: "One piece of the crazy sewing remained unripped. Mrs Peter's back turned, Martha Hale now scrutinized that piece, compared it with the dainty, accurate sewing of the other blocks. The difference was startling. Holding this block made her feel queer, as if the distracted thoughts of the women who had perhaps turned to it to try and quiet herself were communicating themselves to her" (Glaspell, 1918: 7).

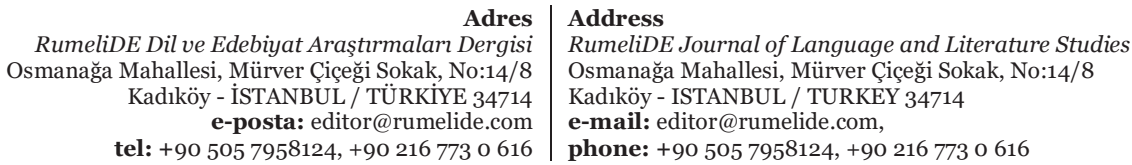


1012 / RumeliDE Journal of Language and Literature Studies 2022.26 (February)

From the Play to the Story: Writers and Readers of A Jury of Her Peers / Y. G. Sertel (pp. 1004-1013)

Reader-response criticism categorizes the literary texts in two groups: "the rhetorical text" and "the dialectical text". In rhetorical texts, there is a tendency to "reflect and reinforce opinions that readers already hold" (Schwarz, 1994: 127). Men of the story see nothing more than a rhetorical text in the kitchen of Minnie since they are conditioned by their own prejudices not only towards Minnie but also towards all women. Therefore, in A Jury of Her Peers, the rhetorical aspect of texts - such as the kitchen tools or the quilt- are related with the female-gender role of Minnie from the male perspective and thus, they are read as signs of Minnie's irresponsibility as a housewife. The rhetorical text does not offer any further connotations to men. On the other hand, "a dialectical text, rather than presenting an opinion as if it were truth, challenges readers to discover truths on their own." In this way, they become texts that "prod and provoke" the reader (Schwarz, 1994: 127). However, while proding and provoking their own truths in reading a dialectical text, the readers have to reject the common appreciations and categorizations in the discourse of the dominant perspectives. Therefore, the rhetorical text constructed in the minds of the male characters have to be rejected and even deconstructed by women in order to appreciate the full meaning of the dialectical texts: "Instead of offering a 'single, sustained argument', a dialectical text [...] may be so arranged that to enter into the spirit and assumption of any one of its [...] units is implicitly to reject the spirit and assumption of the unit immediately preceding" (Schwarz, 1994:127-128). Hence, as woman characters of the story, Mrs Peters and Mrs Hale become the readers of the dialectical text written by Minnie. By reading the messages given in the dialectical texts, they identify themselves with Minnie and they experience an awareness of their common membership in womanhood. As Judith Fetterley suggests, “the reading of woman's texts has the potential of giving woman a knowledge of the self, for putting us in contact with our real selves, which the reading of male texts can not provide" (Fetterley, 1986: 151-152). This self-knowledge, in other words, the female subjectivity is mentioned by Mrs Hale towards the end of the story as follows: "We all go through the same thing - it's all just a different kind of the same thing! If it weren't - why do you and I understand? Why do we know what we know this minute?” (Glaspell, 1918: 10)

\section{Conclusion}

In The Reading Process: A Phenomenological Approach, Wolfgang Iser refers to "two poles" of a literary text which are "the artistic and the aesthetic: the artistic refers to the text created by the author, and the aesthetic to the realization accomplished by the reader" (Iser, 1988: 189). In A Jury of Her Peers, the artistic pole of Minnie's texts become her untidy kitchen, kitchen tools, the strangulated bird wrapped in a silk and the quilt with its irregularities and disorders whereas the aesthetic pole of the texts in question take us to what Mrs Peters and Mrs Hale understand from those texts. This comprehension initiates a self-realization and even a transformation in the female characters. Instead of being only obedient wives, they decide to be autonomous women who understand and support each other: "Slowly, unwillingly Mrs Peters turned her head until her eyes met the eyes of the other woman. There was a moment when they held each other in a steady, burning look in which there was no evasion nor flinching. Then Martha Hale's eyes pointed the way to the basket in which was hidden the thing that would make certain the conviction of the other woman"(Glaspell, 1918: 11). Since woman characters are supported with the power of their sisterhood, the reality of the murder becomes their hidden secret buried forever in their female subjectivity.

A Jury of Her Peers is a meta-text of a murder mystery written by a woman Susan Glaspell which also explains the story of the texts written and read by women. Since reader-response criticism refers to the significance of various texts which offer various meanings for various readers, readers of A Jury of Her Peers enjoy the opportunity of reading the texts of the absent protagonist Minnie Wright both from the

\footnotetext{
Adres $\mid$ Address

RumeliDE Dil ve Edebiyat Araştırmaları Dergisi Osmanağa Mahallesi, Mürver Çiçeği Sokak, No:14/8 Kadıköy - İSTANBUL / TÜRKIYE 34714 e-posta: editor@rumelide.com

RumeliDE Journal of Language and Literature Studies

Osmanağa Mahallesi, Mürver Çiçeği Sokak, No:14/8

Kadıköy - ISTANBUL / TURKEY 34714

e-mail: editor@rumelide.com,

tel: +90 5057958124, +902167730616 phone: +90 5057958124, +90 2167730616
} 
perspective of men who become the actual readers and from the perspective of women who become the implied readers. While the actual readers/male characters only see a rhetorical text before them which prevents them to solve the mystery of the murder, the implied reader/female characters can read all the messages coded in the dialectical text by Minnie who is the main suspect of the murder. However, women reject to share the information they have acquired from the text of Minnie with their men who are in fact, the real investigators of the murder. In doing so, they both protect Minnie from the laws and injustices of the male hegemony and they also silently rebel against the patriarchal system which rejects to read woman's texts and woman's lives. The end of the story depicts the silent victory of women's revolt and the mute celebration of women's common membership in womanhood.

\section{References}

American Psychiatric Association. (2013). Diagnostic and Statistical Manual of Mental Disorder. Manual 5 (DSM-5) Washington, London: American Psychiatric Publishing.

Barthes, R. (1988). The Death of the Reader. In Lodge D. (Ed.), Modern Criticism and Theory - A Reader. London:Longman, 145-150.

Bigsby, C.W.E. (2000). Introduction. In Bigsby, C.W.E. (Ed.), Plays by Susan Glaspell. Cambridge: Cambridge University Press, 1-31.

Brooker, P. \& Selden, R. \& Widdowson, P. (1997). A Reader's Guide to Contemporary Literary Theory. London \& New York\& Toronto: Prentice Hall.

Carruth, A. \& Logan, C. (2002) Depressive Symptoms in Farm Women: Effects of Health Status and Framing LifeStyle Characteristics, Behaviors and Beliefs. In Journal of Community Health. Vol. 27 , No.3, 213-228.

Chinoy, H. K. \& Jenkins L. W. (1981). Women in American Theater. Lexington \& New York: Crown Publishers.

Fetterley, J. (1986). Reading about Reading: 'A Jury of Her Peers', 'The Murders in the Rue Morgue' and 'The Yellow Wallpaper'. In Flynn, E. \& Schweickart, P. (Ed.), Gender and Reading - Essays on Readers, Texts and Contexts. John Hopkins University Press, 147-164.

Glaspell, S. (1918). A Jury of Her Peers. Every Week. Crowell Publishing Company. 1-11. Nmi.org/wp.content/uploads/2015/01/1345.pdf

Hedges, E. (2002). Small Things Reconsidered, A Jury of Her Peers. In Ben-Zvi, L. (Ed.), Susan Glaspell - Essays on her Theater and Fiction. Ann Arbor: The University of Michigan Press, 49-70.

Hirsch, E.D. (1988). Faulty Perspectives. In Lodge, D. (Ed.). Modern Criticism and Theory - A Reader. London: Longman, 230-240.

Iser, W. (1988). The Reading Process: A Phenomenological Approach. In Lodge, D. (Ed.). Modern Criticism and Theory - A Reader. London: Longman, 188-205.

Schwarz, D. (1994). The Dead -James Joyce. Boston \& New York: MacMillan Press Ltd.

Sözalan, Ö. (2006). The Stage in the Text - Essays on American Drama. İstanbul: Okuyan Us Yayın.

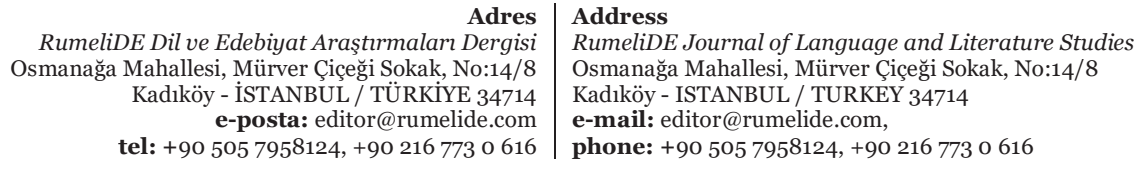

